DOI: $10.2478 / \mathrm{v} 10014-010-0008-\mathrm{y}$

Agrovoc descriptors: feeds,cereals,cereal crops, feed production,biological contamination, fusarium, penicillium, aspergillus, alternaria,moulds,mycotoxins,barley,hordeum,toxic substances

Agris category code: Q53

\title{
The natural occurrence of toxigenic moulds and mycotoxins in Slovenian primary grain production
}

\author{
Breda JAKOVAC-STRAJN ${ }^{\mathrm{a}}$, Anton VENGUŠT ${ }^{\mathrm{b}}$, Igor UJČIČ-VRHOVNIK ${ }^{\mathrm{c}}$, Katarina PAVŠIČ-VRTAČ ${ }^{\mathrm{d}}$, Gabrijela \\ TAVČAR-KALCHER
}

Received December 14, 2009; accepted April 2, 2010.

Delo je prispelo 14. decembra 2009; sprejeto 2. aprila, 2010.

\begin{abstract}
The aim of the present study was to determine the contamination of grains, grown in Slovenia and used for animal diets by Slovene farmers in year 2009. A total of 66 samples was examined on toxigenic moulds from genera Fusarium, Penicillium, Aspergillus, Alternaria and on 8 different mycotoxins. The leading contaminants among moulds were from Fusarium spp., detected in 51 samples, mostly in barley (19). The average number of Fusarium spp. colony forming units (cfu) in different grains was from 5.5$23.3 \times 10^{3} / \mathrm{g}$, whereas the contamination of barley with Penicillium, Aspergillus and Alternaria spp. was 4.5, 19.3 and $5 \times 10^{3} \mathrm{cfu} / \mathrm{g}$. Using liquid (HPLC) and gas chromatography (GC) methods, the presence of various mycotoxins (expressed for $12 \%$ of moisture content) was proved in $57.6 \%$ of all samples; mostly deoxynivalenol (DON, 54.5\%) in concentrations of $130-2860 \mu \mathrm{g} / \mathrm{kg}$, followed by zearalenone (ZON, $15.1 \%, 70-800 \mu \mathrm{g} / \mathrm{kg}$ ), fumonisin B1 (3\%, 120-210 $\mu \mathrm{g} / \mathrm{kg}$ ), while fumonisin $\mathrm{B} 2$, ochratoxin $\mathrm{A}$, diacetoxyscirpenol (DAS), HT-2 and T-2 toxins were not detected. The results indicate that further control of toxigenic moulds and mycotoxins in Slovenian primary grain production is thus required and justified.
\end{abstract}

Keywords: animal feed, grains, grains-microbiology, mycotoxins-analysis, Slovenia

\section{IZVLEČEK}

\section{NARAVNA KONTAMINACIJA ŽIT IZ PRIMARNE PROIZVODNJE V SLOVENIJI S TOKSIGENIMI PLESNIMI IN MIKOTOKSINI}

Z raziskavo smo želeli dobiti vpogled v kontaminacijo žit, ki so jih kmetje $v$ Sloveniji pridelali in uporabili za prehrano živali v letu 2009. Na toksigene plesni iz rodu Fusarium, Penicillium, Aspergillus, Alternaria in 8 različnih mikotoksinov smo preiskali skupno 66 vzorcev. Najbolj razširjene so bile plesni iz rodu Fusarium. Izolirali smo jih iz 51 vzorcev, najpogosteje iz ječmena (19). Njihovo povprečno število kolonij (cfu) je bilo $\mathrm{v}$ različnih žitih od 5,5-23,3 x $10^{3} / \mathrm{g}, \mathrm{v}$ ječmenu pa je bilo $4,5,19,3$ in $5 \times 10^{3} \mathrm{cfu} / \mathrm{g}$ kolonij plesni iz rodu Penicillium, Aspergillus in Alternaria. S tekočinsko (HPLC) in plinsko kromatografijo (GC) smo dokazali različne mikotoksine (rezultati so izraženi pri $12 \%$ vsebnosti vlage vzorca) v $57,6 \%$ vseh preiskanih vzorcev. Največ vzorcev je vsebovalo deoksinivalenol (DON, 54,5\%) v koncentraciji od $130-2860 \mu \mathrm{g} / \mathrm{kg}$, sledijo zearalenon (ZON, $15,1 \%, 70-800 \mu \mathrm{g} / \mathrm{kg})$ in fumonizin $\mathrm{B}_{1}(3 \%, 120-210 \mu \mathrm{g} / \mathrm{kg})$. Fumonizinov $\mathrm{B}_{2}$, ohratoksina $\mathrm{A}$, diacetoksiscirpenola (DAS), HT-2 in T-2 toksina nismo dokazali $\mathrm{v}$ nobenem vzorcu. Rezultati kažejo, da je nadaljnja kontrola toksigenih plesni in mikotoksinov v krmi iz primarne pridelave v Sloveniji vsekakor potrebna in upravičena.

Ključne besede: krma, žita-mikrobiologija, mikotoksinianalize, Slovenija

\footnotetext{
a) University of Ljubljana, Institute for hygiene and pathology of animal nutrition, Gerbičeva 60, 1000 Ljubljana, Slovenia; assist. dr., DVM, MVSc; email: breda.jakovac-strajn@vf.uni-lj.si

b) same address like ${ }^{1}$, sci. councilor, DVM, MVSc

${ }^{\text {c) }}$ same address like ${ }^{1}$, assist., DVM, MVSc

d) same address like ${ }^{1}$, specialist adviser, univ. dipl. chem.

${ }^{\text {e) }}$ same address like ${ }^{1}$, sci. associate, univ. dipl. chem.
} 


\section{INTRODUCTION}

Ubiquitous microorganisms can be found in the air, water, soil and crops, on animals and human beings and in animal feed. Animal feed is thus being contaminated with microorganisms during its production, modification, storage and consumption (Marquardt, 1996; Maciorowski et al., 2007). Certain microbial groups (collective term: field flora of primary flora) can be found on plants predominantly at the time of harvesting. They are described also as product-typical microflora, including saprophytic bacteria (yellow pigmented bacteria, Pseudomonas spp.) and moulds (Fusarium spp., Cladosporium spp., Verticillium spp., Acremonium spp.). During storage, a change in microflora can occur due to the reduction of the content of product-typical microorganisms or due to the reproduction of the spoilage-indicating microflora, adapted to the storage conditions. The main spoilageindicating moulds are Penicillium spp., Aspergillus spp., Scopulariopsis spp., and Mucorales spp. Microorganisms causing spoilage are also all species of yeasts (VDLUFA, $2007 \mathrm{~d}$ ). The growth of moulds is greatly influenced by the water content of the substrate. At low moisture content (usually less than 14-16\%) most storage fungi do not grow or grow very slowly (Smith and Yarrow, 1996).

Some species of mould are able to produce highly toxic compounds called mycotoxins. Different moulds can produce different mycotoxins on the same commodity. These toxins can adversely affect animal health and production and can have harmful effects on humans if transmitted to foods (Marquardt, 1996). However, it has been noted that mycoflora can colonize crops and produce mycotoxins without visible damage. Conversely, signs of fungal infestations do not necessarily correlate with the presence of mycotoxins (Patino et al., 2004).

Until now more than 300 mycotoxins have been identified. In grains, most important mycotoxins, affecting animals' health, are: aflatoxins, ochratoxins, fumonisins, zearalenone (ZON), deoxynivalenol (DON), T-2 toxin and other trichothecenes and ergot alkaloids (Kumar et al., 2008). The most commonly known mycotoxins are aflatoxins due to the fact that they represent one of the most potential carcinogenic substance known so far. Aflatoxins are produced by the moulds of genus Aspergillus. Trichothecenes, most important among them are DON, T-2 toxin, HT-2 toxin and DAS, are in general potent inhibitors of eukaryotic protein synthesis (Bennett and Klich, 2003). Although DON is one of the least acutely toxic trichothecenes, it should be treated as an important food safety issue because of very common contamination of grains. Other trichothecens, T-2 and HT-2 toxins may cause haematological changes and immune suppression, reduced feed intake and skin irritation as well as diarrhoea and haemorrhages of internal tissues. Trichothecenes are mainly produced by the moulds of genus Fusarium, which produce also $\mathrm{ZON}$. ZON is a mycotoxin with strong hyper-estrogenic effects, resulting in impaired fertility, stillbirths of females offsprings and a reduced sperm quality in male animals. Ochratoxin A, which is produced by a number of Aspergillus and Penicillium species, has been listed as possibly carcinogenic to humans. It causes renal toxicity, nephropathy and immune suppression in several animal species, resulting in reduced animal production performance parameters. The most recently described mycotoxins with relevance in human and animal nutrition are fumonisins. They cause severe animal diseases such as equine leukoencephalomalacia (ELEM) in horses, and porcine pulmonary oedema (PPE) in pigs. Fumonisins are produced by a number species from genus Fusarium, as well as Alternaria (Binder, 2007). Recently, the mycotoxin analyses were performed on a total of 2798 samples sourced from Europe, Mediterranean and Asian-pacific region. More than a half of samples of grains and feeds from Europe were contaminated at levels above the limit of quantification of methods applied with DON, ZON and T-2 toxin (Binder et al., 2007).

In Slovenia, there is relatively little information related to the natural occurrence of fungi and mycotoxins in grains. In this context, the aim of this work was to investigate the contamination of grains on toxigenic moulds (Fusarium, Penicillium, Aspergillus and Alternaria) and mycotoxins: ochratoxin A, ZON, DON, DAS, T-2 toxin, HT-2 toxin as well as fumonisins B1 and $\mathrm{B} 2$.

\section{MATERIALS AND METHODS}

\subsection{Sample collection}

The collecting of 66 samples of different grains, grown on Slovene farms, took place in the period between June and August 2009. Samples of raw material were taken directly at the farms. Several incremental samples were taken randomly from the whole lot and combined to the aggregate sample.
After homogenisation and grinding of the aggregate sample in the lab, a laboratory sample of $1.5 \mathrm{~kg}$ was taken for the examination. A total of $100 \mathrm{~g}$ was randomly selected for the analysis of mycoflora, which was done immediately while the other part of the sample was stored at $8{ }^{\circ} \mathrm{C}$ for mycotoxicological analyses. 


\subsection{Isolation and identification of moulds and yeasts}

To examine the contamination of the samples on saprophytic moulds and yeasts, a slightly modified method of Verband Deutscher Landwirtschaftlicher Untersuchungs-und Forschungsanstalten (VDLUFA) was used (VDLUFA, 2007a; $\mathrm{b}$; c; d). To $20 \mathrm{~g}$ of each sample, $180 \mathrm{ml}$ of $0.5 \%$ peptone water was added. The mixture was homogenised using linear shaker for $20 \mathrm{~min}$ and than diluted to final concentration of $10^{-2}, 10^{-3}$ and $10^{-4}$ (VDLUFA, 2007a). $1 \mathrm{ml}$ aliquots of each dilution were spread (in duplicates) on the surface of solid medium, described by Schmidt et al. (1981). The composition of the medium was (per litre) as follows: $40 \mathrm{~g}$ malt extract, $2 \mathrm{~g}$ glucose, $2 \mathrm{~g}$ yeast extract, $1 \mathrm{ml}$ Marlophen $810 \AA$, $60 \mathrm{mg}$ Bengal Rose, $60 \mathrm{mg}$ oxytetracycline-HCl (OTC), 12 g agar, $1000 \mathrm{ml}$ distilled water. Plates were incubated for 3 days at 25 ${ }^{\circ} \mathrm{C}$ in the dark and in the normal atmosphere. Afterwards, plates were stored at room temperature for 2-3 days. Finally, the colonies were counted and the results were expressed as average colony forming units in thousands per gram of sample $\left(10^{3} \mathrm{CFU} / \mathrm{g}\right)$ using the following formula (VDLUFA, 2007c):

$$
N=\frac{\sum C}{V \times n \times d}
$$

$\mathrm{N}=$ number of colony-forming units per gram of sample (CFU/g)

$\Sigma \mathrm{C}=$ sum of all colonies of the count plates

$\mathrm{V}=$ volume of the dilutions pipetted in the count plates in $\mathrm{ml}$

$\mathrm{n}=$ number of count plates that can be evaluated

$\mathrm{d}=$ dilution factor

Taxonomic identifications of different genera of moulds were made visually and where applicable, by means of a magnifying glass or a stereomicroscope. Closer characterisation was possible using a light-optical microscope. In this case, selected parts of colonies were transferred onto a slide using adhesive film (Smith and Yarrow, 1996).

\subsection{Mycotoxins analysis}

2.3.1 Apparatus

Linear shaker IKA HS 501 digital (IKA Labortechnik, Germany) was used for the extraction. For liquid chromatography, the system Waters Alliance 2690 with the fluorescence detector Waters 474 (Waters, MA, USA) equipped with columns Prodigy $5 \mu \operatorname{ODS}(2)$ and Synergy $4 \mu$ Hydro-RP 80A (Phenomenex, CA, USA) in the case of aflatoxin $\mathrm{B}_{1}$ and fumonisins, respectively and with Hypersil ODS $5 \mu \mathrm{m}$ (Thermo Scientific, MA, USA) in the case of ochratoxin A and ZON was used. For the post column derivatisation, either Kobra cell (Rhône diagnostics, Scotland) or post-column reactor RXN 1000 (Waters) was mounted between chromatographic column and fluorescence detector. Trichothecenes (DON, DAS, T-2, HT-2) were determined by gas chromatography with mass spectrometry (GC-MS), using system HP 6890 Series (Hewlett Packard, CA, USA) with mass selective detector 5975B inert XL (Agilent Technologies, CA, USA). The column was HP-5MS, $30 \mathrm{~m}$, $0.25 \mathrm{~mm}$ I.D., $0.25 \mu \mathrm{m}$ (Agilent Technologies) and helium with a flow rate of $1 \mathrm{ml} / \mathrm{min}$ was used as the carrier gas.

\subsubsection{Chemicals and reagents}

Standard solutions of aflatoxin $\mathrm{B}_{1}$, ochratoxin $\mathrm{A}, \mathrm{ZON}$ and fumonisins $B_{1}$ and $B_{2}$ were purchased from Biopure (Tulln, Austria) and a standard solution of trichothecenes (including DON, DAS, HT-2, and T-2) was purchased from R-Biopharm Rhône (Glasgow, Scotland). For sample clean-up, immunoaffinity columns (R-Biopharm Rhône) and Mycosep 227 Trich+ (Romer Labs, MO, USA) were used. Reagents purchased at Merck (Darmstadt, Germany) and Supelco (PA, USA) were of analytical or chromatography grade purity.

\subsubsection{Analytical procedure}

Aflatoxin B1, ochratoxin A, zearalenone, and fumonisins were determined following the instruction for use enclosed to immunoaffinity columns and a standard (R-Biopharm Rhône, 2003a, b, c; 2005; European Committee for Standardization, 2004). For the determination of trichothecenes, the procedure based on analytical methods described by Radová et al. (1998), Langseth and Rundberget (1998), Tanaka et al. (2000), Melchert and Pabel (2004), and Schothorst et al. (2005) was used.

Mycotoxins were extracted from samples with appropriate solvents. After sample clean-up, mycotoxins were determined by liquid chromatography or GC-MS. Before the detection, aflatoxin $\mathrm{B}_{1}$ was derivatised with bromine in Kobra cell and fumonisins were derivatised with o-phtaldialdehyde and $\mathrm{N}$ acetyl-L-cystein in the post-column reactor.

The limit of detection (LOD) and the limit of quantification (LOQ) for aflatoxin $B_{1}$ were 0.2 and $0.6 \mu \mathrm{g} / \mathrm{kg}$, respectively. LOD and LOQ for ochratoxin A were 10 and $30 \mu \mathrm{g} / \mathrm{kg}$, for ZON 20 and $50 \mu \mathrm{g} / \mathrm{kg}$, for fumonisins $\mathrm{B}_{1}$ and $\mathrm{B}_{2} 30$ and 100 $\mu \mathrm{g} / \mathrm{kg}$, and for DON, DAS, T-2 and HT-2 50 and $100 \mu \mathrm{g} / \mathrm{kg}$. To enable the comparison between samples and their estimation regarding recommended European guidance values (European Commission, 2006) the results of mycotoxicological analysis were recalculated to a sample moisture content of $12 \%$. Samples with the concentration of mycotoxins higher than LOD were designated as positive.

\subsection{Statistical analysis}

The statistical analysis was performed using the statistical program SPSS (Statistical Package for Social Sciencies, Version 12, November 2003). The number of positive samples, arithmetic mean and median of positive samples as well as the maximum level were calculated.

\section{RESULTS}

\subsection{The contamination of grain samples with toxigenic moulds}

The microorganisms, isolated from all 66 samples are shown in Table 1. Because of a small number of triticale (3), fodder pea (2), oats (1) and rye (1), these samples were presented together under the label "other". The leading contaminant among moulds was Fusarium spp., detected in 51 of 66 samples $(77.2 \%)$. Maize had the highest average number of growth colonies of Fusarium spp. and Penicillium spp. The samples of barley 
contained the highest average number of Aspergillus spp. and Alternaria spp. colonies.

Table 1: The presence of toxigenic moulds in grain samples.

\begin{tabular}{|c|c|c|c|c|c|}
\hline \multicolumn{6}{|c|}{ Samples of grain } \\
\hline & Barley & Maize & Wheat & Other & Total \\
\hline Number of samples & 23 & 18 & 18 & 7 & 66 \\
\hline $\begin{array}{c}\text { Micro- } \\
\text { organisms }\end{array}$ & & $\begin{array}{r}\text { (num. } \\
\text { mean } \\
\text { max.level }\end{array}$ & 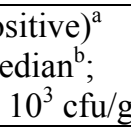 & & ${\text { (num. positive })^{\mathrm{d}}}_{\%}$ \\
\hline Fusarium & $\begin{array}{c}(19) \\
5.5 / 5.0 \\
17.0\end{array}$ & $\begin{array}{c}(12) \\
23.3 / 8.0 \\
128.0\end{array}$ & $\begin{array}{c}(15) \\
5.2 / 6.0 \\
12.0\end{array}$ & $\begin{array}{c}(5) \\
6.6 / 8.0 \\
11.0\end{array}$ & $\begin{array}{l}(51) \\
77.2\end{array}$ \\
\hline Penicillium & $\begin{array}{c}(11) \\
4.5 / 2.0 \\
12.0\end{array}$ & $\begin{array}{c}(6) \\
8.8 / 5.5 \\
30.0\end{array}$ & $\begin{array}{c}(9) \\
4.4 / 4.0 \\
11.0\end{array}$ & $\begin{array}{l}(1) \\
8.0\end{array}$ & $\begin{array}{l}(27) \\
40.9\end{array}$ \\
\hline Aspergillus & $\begin{array}{c}(11) \\
19.3 / 4.0 \\
100\end{array}$ & $\begin{array}{c}(9) \\
10.4 / 7.0 \\
38.0\end{array}$ & $\begin{array}{c}(5) \\
8.6 / 9.0 \\
16.0\end{array}$ & $\begin{array}{c}(3) \\
11.3 / 13.0 \\
20.0\end{array}$ & $\begin{array}{l}(28) \\
42.2\end{array}$ \\
\hline Alternaria & $\begin{array}{c}(14) \\
5.0 / 2.0 \\
26.0\end{array}$ & $\begin{array}{l}(1) \\
5.0\end{array}$ & $\begin{array}{l}(10) \\
1.5 / 1.5 \\
3.0\end{array}$ & $\begin{array}{c}(4) \\
2.0 / 2.0 \\
3.0\end{array}$ & $\begin{array}{l}(29) \\
43.9\end{array}$ \\
\hline
\end{tabular}

${ }^{a}$ Number of positive samples.

${ }^{\mathrm{b}}$ Arithmetic mean/median of positive samples in $\times 10^{3} \mathrm{cfu} / \mathrm{g}$.

${ }^{\mathrm{c}}$ Maximum level detected in $\mathrm{x} 10^{3} \mathrm{cfu} / \mathrm{g}$.

${ }^{\mathrm{d}}$ Total number of positive samples regarding one microorganism.

\subsection{The contamination with mycotoxins}

A total of 66 grain samples was analysed, resulting in 528 analyses. Table 2 gives an overview of contamination grade of the tested samples, stating the total number of each sample tested, the number of positives, arithmetic mean and median of positive samples as well as the maximum level. In cases, where one sample was positive, the value is presented with one number. The samples of maize were most frequently contaminated and contained DON, ZON and fumonisin
B1. Generally, in most samples, DON was detected $(54.5 \%)$. It was proven in 15 out of 18 samples of wheat, as well as in all other grain samples. DON was closely followed by ZON, which was detected in all grain samples. Fumonisin B1 was detected only in 2 maize samples.

Ochratoxin A, DAS, T-2 toxin and HT-2 were under the detection limit in all analysed samples. 
Table 2: Occurrence of mycotoxin contamination in grain samples (results expressed for 12\% moisture content).

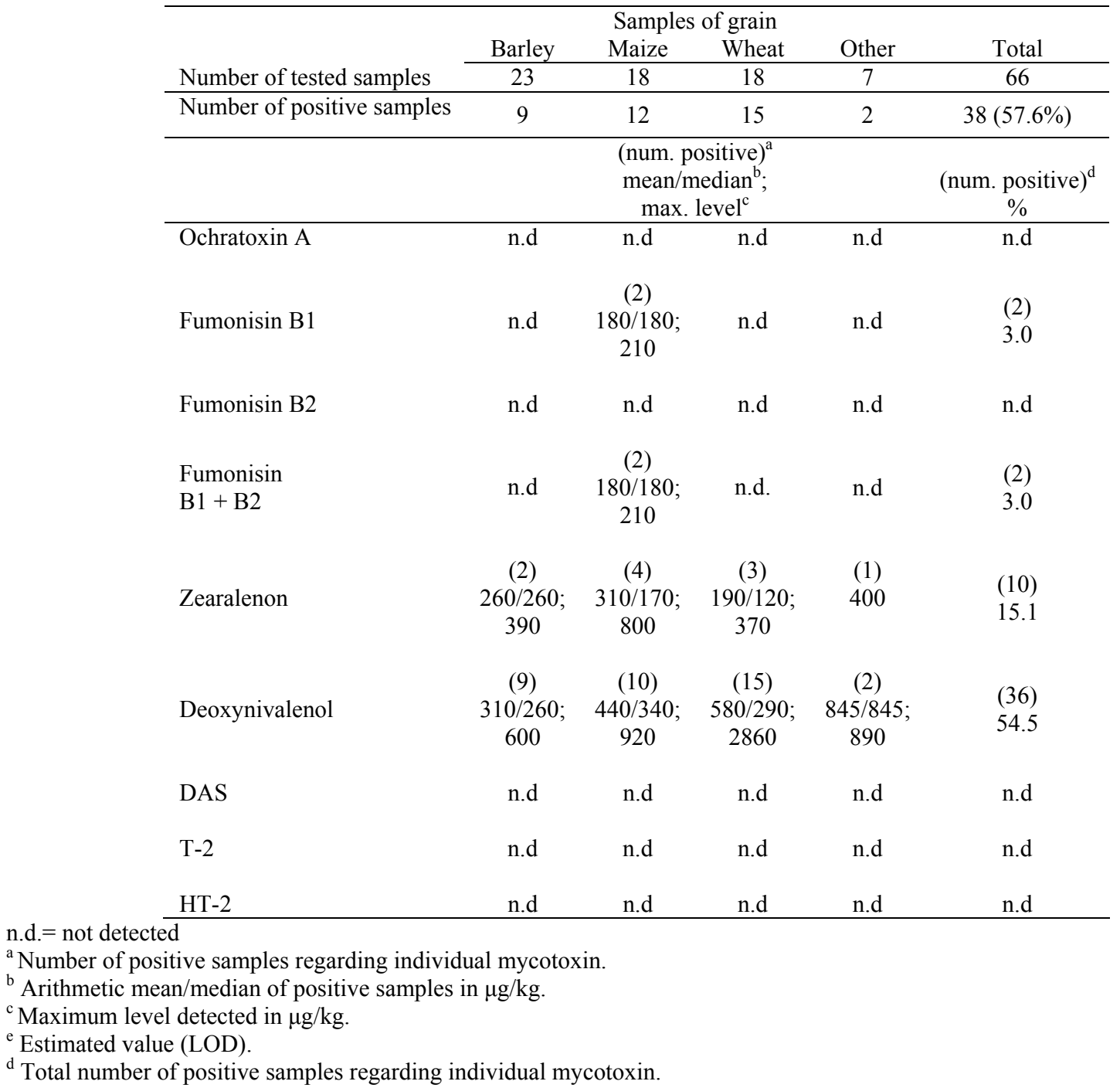

n.d. $=$ not detected

\section{DISCUSSION}

Mycrobiological examination proved that $77.2 \%$, $40.9 \%, 42.2 \%$ and $43.9 \%$ of the samples of different grains contained moulds of genera Fusarium, Penicillium, Aspergillus and Alternaria, respectively. As a result of this contamination, the $57.6 \%$ of samples were positive to at least one mycotoxin.

Slovenia, like all other EU countries, has no written legislative limits regarding the mycrobiological status of animal feed. There are no official methods for detection of the microbial contamination. With traditional culturing methods, used also in our study, it takes 5-7 days to get results. Molecular methods hold promise as a viable technology to reach these results, but will require considerable optimisation and standardisation before this becomes routine in the animal feed industry
(Maciorowski et al., 2007). Most of the countries tend to set general standards in the field of microbiological examinations, but agreement and setting of international regulatory standards is very difficult, as not only potential health benefits but also political and economic issues have to be considered.

The average contamination with colonies of Fusarium spp. in maize were lower than in previous years, when the average contamination was $250 \times 10^{3} \mathrm{cfu} / \mathrm{g}$ and for Penicillium and Aspergillus 744 and $7 \times 10^{3} \mathrm{cfu} / \mathrm{g}$ (Jakovac-Strajn et al., 2008). The moulds from genus Alternaria had the highest average number in barley. Based on the number of positive samples of all grains $(43.9 \%)$, the potential presence of toxins such as 
tenuazonic acid, alternariol and alternariol monomethyl ether may pose a contamination risk.

It is well known, that environmental conditions have great influence on the development and spread of moulds and consequently on the production of mycotoxins. Water stress, temperature stress and insect damage of a host plant are, under field conditions, the major determining factors of mould infestation and toxin production. With stored grain, factors which are likely to affect mycotoxin formation include moisture content and the composition of the substrate, environmental temperature, exposure time, damage to seeds, oxygen availability, carbon dioxide concentrations, fungal abundance, prevalence of toxic strains, spore loads, microbial interaction and invertebrate vectors, particularly insects. Spoilage, fungal growth and mycotoxin formation result from the complex interactions of these factors (Abramson et al., 1980; Santin, 2005).

There are also great differences in sensibility to mycotoxins among individual animal species. Factors such as breed, sex, environment, nutritional status, as well as other toxic entities can affect the symptoms of intoxication and may contribute to the significance of mycotoxin damage on economic output and animal health (Binder, 2007). Many countries have, therefore, established measures to control the contamination of these toxins in foodstuffs and animal feed. However, Slovenia and EU have, besides a Commission Recommendation on the presence of DON, ZON, ochratoxin A, T-2 and HT-2 and fumonisins (European Commission, 2006), placed legislative limits only for aflatoxin B1 in feed for different species and categories of livestock. Aflatoxin B1 concentrations in animal feed, grains being among them, may thus range up to $0.02 \mathrm{mg} / \mathrm{kg}$ of feed (European Commission, 2003a), but this mycotoxin was not the aim of our study. For DON, $\mathrm{ZON}$, ochratoxin A and for the sum of fumonisins B1 and $\mathrm{B} 2$, the recommended highest concentration per $\mathrm{kg}$ in cereals and cereal products is $8 \mathrm{mg}, 2 \mathrm{mg}, 0.25 \mathrm{mg}$ and $60 \mathrm{mg}$, respectively. Recommended maximum levels for T-2 and HT-2 toxin have not been set in Europe yet.
The levels of mycotoxins in our research did not reach the recommended levels, which is very satisfying. In general, our results are similar to those reported from around the world. DON is most widely spread mycotoxin, which is confirmed also by the investigation including samples from eleven European countries examined on trichothecenes contents. $57 \%$ of the samples were DON positive $(0.003-3.7 \mathrm{mg} / \mathrm{kg})$, mostly maize, and 20\% contained T-2 toxin and HT-2 toxin (European Commission, 2003b; JECFA, 2001). Maize is known to be a good substrate for mould infection and production of potentially dangerous mycotoxins harmful to both humans and animals (Kumar et al., 2008), but in our investigation wheat was the most contaminated grain with DON, which has happened for the first time. Up to the present, also in Slovenia maize was the most contaminated grain (Jakovac-Strajn et al., 2008).

In neighbouring Croatia, a seven year long investigation of grains or animal feed samples (1998-2004) revealed $41 \%$ of DON, $16.8 \%$ of T-2 toxin and $27.6 \%$ of DAS (Sokolović and Šimpraga, 2006). In former investigations (Domijan et al., 2005), maize samples were tested on ochratoxin A, ZON and fumonisins B1 and B2. Most frequently fumonisin B1 was found (100\%), followed by ZON (84\%) and ochratoxin A $(39 \%)$, while fumonisin B2 was found only in three samples. The concentrations (mean $\pm \mathrm{SD}$ ) of fumonisin $\mathrm{B} 1, \mathrm{ZON}$ and ochratoxin $\mathrm{A}$ in positive samples were $459.3 \pm 310.7,3.84 \pm 6.68$ and $1.47 \pm 0.38 \mu \mathrm{g} / \mathrm{kg}$, respectively. In 2008, (Jajić et al., 2008) the results of the first examinations on DON in 139 samples of various grains were published. DON was found in $44.7 \%$ of maize samples, $37.5 \%$ of wheat and $25 \%$ of barley samples. In positive samples, DON was found in concentration range between $40-2460 \mu \mathrm{g} / \mathrm{kg}$, but in our research in concentration at $130-2860 \mu \mathrm{g} / \mathrm{kg}$.

Taken together, the presence of toxigenic moulds in different grains grown in Slovenia showed and confirmed the presence of different mycotoxins, which were consumed by livestock. Although concentrations were not above the recommended levels, a relatively high percent of positive samples $(57.6 \%)$ require a further control in Slovenian primary grain production.

\section{REFERENCES}

Abramson, D., Sinha, R. N., Mills, J. T. (1980). Mycotoxins and odor formation in moist cereal grain during granary storage. Cereal Chemistry, 57: 346-351.

Bennett, J. W., Klich, M. (2003). Mycotoxins. Clinical Microbiology Reviews, 16(3): 497-516.

Binder, E. M. (2007). Managing the risk of mycotoxins in modern feed production. Animal Feed Science and Technology, 133: 149-166.
Binder, E. M., Tan, L. M., Chin, L. J., Handl, J., Richard, J. (2007). Worldwide occurrence of mycotoxins in commodities feeds and feed ingredients. Animal Feed Science and Technology, 137: 265-282.

Domijan, A. M., Peraica, M., Jurjević, Z., Ivić, D., Cvjetković, B. (2005). Fumonisin B1, fumonisin B2, zearalenone and ochratoxin A contamination of maize in Croatia. Food Additives and Contaminants, 22(7): 677-680. 
European Commission (2003a). Commission directive 2003/100/EC of 31 October 2003, amending Annex I to Directive 2002/32/EC of the European Parliament and of the Council on undesirable substances in animal feed. Official Journal of European Union, L 285: 3337.

European Commission (2003b). Collection of occurrence data of Fusarium toxins in food and assessment of dietary intake by the population of EU member states. European Commission. Report on Task for Scientific Cooperation (SCOOP) 3.2.10 EC Brussels. http://ec.europa.eu/food/fs/scoop/task3210.pdf

European Commission (2006). Commission recommendation of 17 August 2006 on the presence of deoxynivalenol, zearalenone, ochratoxin A, T-2 and HT-2 and fumonisins in products intended for animal feeding. Official Journal of European Union, L 229: 7-9.

European Committee for Standardization (2004). Foodstuffs Determination of fumonisin B1 and B2 in maize based foods - HPLC method with immunoaffinity column clean up, EN 14352. European Committee for Standardization, Brussels.

Jajić, I., Jurić, V., Abramovic, B. (2008). Occurrence of deoxynivalenol in maize and wheat in Serbia. International Journal of Molecular Sciences, 9: 21142126.

Jakovac-Strajn, B., Vengušt, A., Pestevšek, U., TavčarKalcher, G., Ujčič-Vrhovnik I., Vrtač-Pavšič, K. (2008). Mikrobiološke in mikotoksikološke preiskave žitaric $\mathrm{v}$ Sloveniji $=$ Microbiological and mycotoxicological examinations of grains grown in Slovenia. V: Zbornik predavanj - 17. Mednarodno znanstveno posvetovanje o prehrani domačih živali "Zadravčevi-Erjavčevi dnevi" : Radenci, 2008-1113/14. Murska Sobota: Kmetijsko gozdarska zbornica Slovenije, Kmetijsko gozdarski zavod, str. 41-50.

JECFA (2001). Evaluation of certain mycotoxins in food. WHO Technical Report Series 906. Joint FAO/WHO Expert Committe on Food Additives. 56th Report. Geneva. Switzerland.

Kumar, V., Basu, M. S., Rajendran, T. P. (2008). Mycotoxin research and mycoflora in some commercially important agricultural commodities. Crop Protection, 27: 891-905.

Langseth, W., Rundberget, T. (1998). Instrumental methods for the determination of nonmacrocyclic trichothecenes in cereals, foodstuffs and cultures. Journal of Chromatography A, 815: 103-121.

Maciorowski, K. G., Herrera, P., Jones, F. T., Pillai, S. D., Ricke, S. C. (2007). Effects on poultry and livestock of feed contamination with bacteria and fungi. Animal Feed Science and Technology, 133: 109-136.

Marquardt, R. R. (1996). Effects of molds and their toxins on livestock performance: a western Canadian perspective. Animal Feed Science and Technology, 58: 77-89.
Melchert, H. U., Pabel, E. (2004). Reliable identification and quantification of trichothecenes and other mycotoxins by electron impact and chemical ionization-gas chromatography-mass spectrometry, using an ion-trap system in the multiple mass spectrometry mode. Candidate reference method for complex matrices. Journal of Chromatography A, 1056: 195-199.

Patino, B., Mirete, S., Gonzalez-Jaen, M. T., Mule, G., Rodriguez, M. T., Vazquez, C. (2004). PCR detection assay of fumonisin-producing Fusarium verticillioides strains. Journal of Food Protection, 67: 1278-1283.

R-Biopharm Rhône (2003a). Quantitative Detection of Ochratoxin A, Instructions for use.

R-Biopharm Rhône (2003b). Easi-Extract Zearalenone for Sample Clean-up Prior to Detection of Zearalenone Using HPLC Analysis, Instructions for Use.

R-Biopharm Rhône (2003c). Fumoniprep for detection of fumonisins B1, B2 and B3 using HPLC, Instructions for Use.

R-Biopharm Rhône (2005). Application of immunoaffinity columns for sample clean-up prior to HPLC analysis for aflatoxins, Instruction for use.

Radová, Z., Holadová, K., Hajšlová, J. (1998). Comparison of two clean-up principles for the determination of trichothecenes in grain extract. Journal of Chromatography A, 829: 259-267.

Santin, E. (2005). Mould growth and mycotoxin production. In D.E. Diaz, The mycotoxin blue book (pp. 225-235). Nottingham: University Press.

Schmidt, H. L., Bucher, E., Spicher, G. (1981). Keimgehaltbestimmung von Bakterien, Schimmelpilzen und Hefen in Futtermitteln. Nährböden und Methodik. Landwirtschaftliche Forschung, 34(4): 242-50.

Schothorst, R. C., Jekel, A. A., Van Egmond, H. P., De Mul, A., Boon, P. E., Van Klaveren, J. D. (2005). Determination of trichothecenes in duplicate diets of young children by capillary gas chromatography with mass spectrometric detection. Food Additives and Contaminants, 22: 48-55.

Smith, M. T., Yarrow, D. (1996). Identification of the common food borne fungi. In R. A. Samson, E. S. Hoekstra, J. C. Frisvald, O. Filtenborg, Introduction to food-borne fungi (pp. 3-232) . Baarn: Centraalbureau voor schimmelcultures.

Sokolović, M., Šimpraga, B. (2006). Survey of trichothecene mycotoxins in grains and animal feed in Croatia by thin layer chromatography. Food Control, 17: 733-740.

VDLUFA (2007a). Standard operation procedure for the enumeration of micro-organisms using solid culture media. In VDLUFA Method Book III, Suppl. 7 (ch. 28.1.1., 14 p). Darmstadt: VDLUFA.

VDLUFA (2007b). Standard operation procedure to enumerate bacteria, yeasts, moulds, and Dematiaceae. In VDLUFA Method Book III, Suppl. 7 (ch. 28.1.2., 18 p). Darmstadt: VDLUFA.

Acta agriculturae Slovenica, 95 - 2, julij 2010 
VDLUFA (2007c). Standard operating procedure for identifying bacteria, yeasts, moulds and dematiaceae as product-typical and spoilage indicating microorganisms in feeds. In VDLUFA Method Book III, Suppl. 7 (ch. 28.1.3., 11 p). Darmstadt: VDLUFA.

VDLUFA (2007d). Standard operating procedure for microbiological quality assessment. In VDLUFA Method Book III, Suppl. 7 (ch. 28.1.4., 16 p). Darmstadt: VDLUFA.
Tanaka, T., Yoneda, A., Inoue, S., Sugiura, Y., Ueno, Y. (2000). Simultaneous determination of trichothecene mycotoxins and zearalenone in cereals by gas chromatography-mass spectrometry. Journal of Chromatography A, 882: 23-28. 